\title{
Importance Performance Analysis Pelaku Usaha UMKM Sektor Kuliner di Pekanbaru
}

\author{
Oleh:
}

\author{
Afred Suci \\ Universitas Lancang Kuning \\ email: afredsuci@unilak.ac.id
}

Tingginya jumlah pelaku kuliner UMKM di Pekanbaru mendorong munculnya upaya-upaya para pelaku usaha untuk memiliki keunggulan dibandingkan kompetitor, khususnya dalam hal keunggulan pelayanan. Tujuan penelitian ini dilakukan adalah untuk menganalisis persepsi pelanggan pada pelayanan kuliner di sejumlah pelaku usaha UMKM di Pekanbaru. Populasi penelitian terdiri dari para pelanggan rumah makan, dimana sampel terdiri dari 145 orang pelanggan yang dipilih secara convenience sampling. Variabel penelitian adalah kualitas pelayanan kuliner DINESERV yang terdiri dari 5 dimensi yaitu: bukti fisik, kehandalan, daya tanggap, jaminan dan empati. Analisa data menggunakan Importance Performance Analysis (IPA). Hasil penelitian menunjukkan bahwa rata-rata kualitas pelayanan kuliner sudah memuaskan yaitu pada dimensi jaminan (80\%), empati (70\%0, daya tanggap (69\%) dan kehandalan (66\%), kecuali pada dimensi bukti fisik yang masih kurang memuaskan $(58 \%)$. Aspek-aspek kualitas pelayanan kuliner yang masih perlu diperbaiki adalah: area parkir, dekorasi rumah makan, kenyamanan dan kebersihan area makan, ketepatan pelayanan di jam-jam sibuk serta menu yang mudah dibaca dan menarik.

\section{Kata Kunci: Kualitas Pelayanan, Kepuasan, Kuliner.}

The highest number of micro small enterprises (MSE) in culinary business generates enterpreneur's efforts to gain their service excellence. The aim of this study is to analyze customers' perception of culinary service quality in several MSE's culinary enterprises. Population are culinary customers consist of 145 respondents selected by convenience sampling technique. Variables are culinary service quality DINESERV that consists of 5 dimensions are: tangible, reliability, responsiveness, assurance and emphaty. Data analyzed by using Importance Performance Analysis (IPA). The study reveals that averagely the culinary service quality is aleady satisfied in 4 dimension that are: assurance (80\%), emphaty (70\%), responsiveness (69\%) and reliability (66\%), unless for tangible aspect that is still less satisfied (58\%). The culinary service qualities that are needed to be enhanced are: parking area, decoration, dining area comfortness and tidiness, peak hous service punctuality, readable and attractiveness of menu.

\section{Keywords: Culinary Serive Quality, Satisfaction, Micro-small Enterprises}

\section{PENDAHULUAN}

Walaupun Indonesia sudah mampu menembus ke dalam jajaran 20 besar negara dengan ekonomi terbesar di dunia, akan tetapi permasalahan pengangguran masih menjadi isu utama bagi pemerintah. Untuk itu, maka solusi 
yang dilakukan pemerintah Indonesia adalah mendorong tumbuhnya wirausahawirausaha baru, khususnya dari sektor Usaha Mikro Kecil Menengah (UMKM). Sektor ini dipilih dikarenakan populasinya mencapai $99 \%$ dari total unit usaha di Indonesia atau hanya ada 1\% usaha skala besar. Wirausaha sektor UMKM mampu menyerap tenaga kerja hingga 97\% dari total angkatan kerja yang ada. Dengan asumsi bahwa 1 unit wirausaha UMKM mampu menyerap minimal 3-5 tenaga kerja, maka diharapkan munculnya para wirausahawan baru yang akan dapat membantu pemerintah menurunkan tingkat pengangguran secara signifikan dan menjaga stabilitas pertumbuhan ekonomi (Suroto, et al, 2015).

Sektor usaha mikro, kecil dan menengah yang banyak dipilih oleh para pelaku UMKM adalah kuliner. Bisnis usaha dalam bidang kuliner dinilai menjanjikan karena makanan adalah salah satu kebutuhan pokok manusia (Zuari et al, 2013). Syuhada (2014) menemukan bahwa dengan mendirikan usaha-usaha pangan dapat membantu pemerintah untuk mengurangi angka pengangguran dan menyerap tenaga kerja serta sekaligus dapat meningkatkan pendapatan yang diterima masyarakat terutama pelaku usaha UMKM.

Pekanbaru sebagai ibukota Provinsi Riau memiliki perkembangan UMKM yang cukup tinggi. Data dari Dinas Koperasi \& UKM Riau pada tahun 2016 menunjukkan jumlah UMKM di Pekanbaru merupakan yang tertinggi dibandingkan dengan kabupaten/kota lainnya di Provinsi Riau dengan jumlah 68.728 unit, disusul Kampar (45.446 unit) dan ketiga Indragiri Hilir (44.891 unit) (admin UKM, 2016). Dengan tingginya jumlah pelaku UMKM di Pekanbaru maka dibutuhkan upaya-upaya para pelaku usaha tersebut untuk memiliki keunggulan dibandingkan pesaing. Hal ini juga disimpulkan oleh Zuari, et al., (2013) bahwa usaha kuliner tidak dapat hanya bergantung pada cita rasa makanan, melainkan juga harus memperhatikan penerapan strategi pemasaran mengingat tingkat persaingan yang sangat tinggi di sektor kuliner.

Industri kuliner merupakan kolaborasi produk dan jasa dalam komposisi yang berimbang, dan oleh karena itu faktor pelayanan merupakan satu elemen yang sangat strategis dalam upaya pemasaran kuliner. Terdapat sejumlah harapan yang dimiliki konsumen terhadap pelayanan dimana atribut seperti kecepatan layanan, lokasi, kualitas makanan dan kebersihan lokasi kuliner kerap menjadi pertimbangan utama bagi konsumen (Mason, et.,al., 2013). Demikian pula dengan aspek keakurasian tagihan, kebersihan toilet, staf yang bersih dan rapi serta area makan yang bersih juga menjadi harapan konsumen pada sebuah tempat makan (Markovic, et.,al., 2010). Andreani (2010) dalam penelitiannya juga menyimpulkan lima atribut tempat kuliner yang penting adalah kebersihan, rasa, kesopanan, ketepatan penyajian dan keramahan.

Secara umum permasalahan pelayanan masih merupakan kendala bagi terciptanya kepuasan pelanggan secara maksimal terhadap sektor usaha kuliner di Pekanbaru. Penelitian ini mengadopsi 29 indikator pelayanan yang disebut dengan DINESERV dari penelitian Markovich, et al, (2010) yang secara garis besar merupakan pengembangan indikator berdasarkan dimensi SERVQUAL yang terdiri dari: Tangible (bukti fisik); Reliability (keandalan); Responsiveness (daya tanggap); Assurance (jaminan); Emphaty (empati). 


\section{TINJAUAN PUSTAKA}

Sektor usaha skala kecil dan menengah di bidang kuliner sangat bergantung kepada kepuasan yang dirasakan oleh para pelanggan, karena menurut Schnaars (dalam Tjiptono \& Candra, 2007:199) tujuan sebuah bisnis adalah menciptakan para pelanggan yang puas. Namun faktanya, tingkat harapan yang dirasakan oleh konsumen masih belum dapat dipenuhi secara optimal oleh banyak pengelola usaha kuliner, sehingga masih ditemukan sejumlah aspek pelayanan kuliner yang masih kurang memuaskan. Fornell (dalam Tjiptono, 2008:169) mendefinisikan kepuasan sebagai evaluasi purnabel keseluruhan yang membandingkan persepsi kinerja dengan ekspektasi pra-pembelian. Antara harapan dengan persepsi kinerja bisa memunculkan kesenjangan (gap). Adanya kesenjangan jasa akan berdampak pada kepuasan pelanggan. Semakin lebar kesenjangan, semakin tidak puas pelanggan, dan demikian pula sebaliknya, semakin kecil kesenjangan kualitas jasa, maka pelanggan akan semakin merasakan kepuasan (Kotler \& Keller, 2007:55).

Terdapat sejumlah harapan yang dimiliki konsumen terhadap pelayanan kuliner dimana atribut seperti kecetapan layanan, lokasi, kualitas makanan dan kebersihan restoran kerap menjadi pertimbangan utama bagi konsumen (Mason, et al, 2013). Demikian pula dengan aspek keakurasian tagihan, kebersihan toilet, staf yang bersih dan rapi serta area makan yang bersih juga menjadi harapan konsumen pada sebuah restoran (Markovic, et al, 2010). Andreani (2010) dalam penelitiannya juga menyimpulkan lima atribut restoran yang penting adalah kebersihan, rasa, kesopanan, ketepatan penyajian dan keramahan.

\section{METODE PENELITIAN}

\section{Populasi dan Sampel}

Populasi pada penelitian ini adalah pelanggan di tempat-tempat usaha kuliner skala UMKM di Pekanbaru yang tidak diketahui secara pasti jumlahnya. Oleh karena populasi termasuk non probability sampling, maka penetapan jumlah sampel mengacu kepada saran dari Hair sebanyak paling sedikit 5 kali jumlah indikator variabel yang digunakan (Ferdinand, 2006:191). Jumlah indikator yang digunakan dalam penelitian ini adalah 29 item, dan jumlah pengalian yang digunakan adalah 5, sehingga dengan demikian, ukuran sampelnya menjadi: Total sampel $=5 \times 29=145$ responden. Dengan demikian maka jumlah sampel atau responden dalam penelitian ini adalah sebanyak 145 orang pelanggan kuliner UMKM di Pekanbaru. Lokasi pengambilan sampel dilakukan di tempat usaha kuliner Pekanbaru. Adapun metode penentuan sampel dilakukan dengan teknik convenience sampling.

\section{Variabel}

Variabel penelitian ini adalah kualitas pelayanan kuliner yaitu DINESERV yang merupakan pengembangan dari 5 dimensi SERVQUAL yaitu: Tangible (bukti fisik) terdiri dari 11 indikator; Reliability (keandalan) terdiri dari 8 indikator; Responsiveness (daya tanggap) terdiri dari 4 indikator; Assurance (jaminan) terdiri dari 2 indikator; Emphaty (empati) terdiri dari 4 indikator. 


\section{Alat Analisis}

Analisis data dilakukan secara deskriptif, dengan melakukan pembandingan antara nilai rata-rata (mean) tingkat harapan responden dengan nilai rata-rata kinerja pelayanan yang dirasakan. Langkah berikutnya adalah menggunakan Importance Performance Analysis (IPA).

\section{HASIL DAN PEMBAHASAN}

Hasil penelitian terkait penilaian responden pada variabel DINESERV ditunjukkan melalui tabel berikut:

\section{Tabel 1}

Rekapitulasi Tingkat Kepuasan Responden

\begin{tabular}{|c|c|c|c|c|c|c|c|}
\hline No & Variabel & Indikator & $\mathrm{H}$ & K & $\begin{array}{c}\text { Indeks } \\
\text { Kepuasan }\end{array}$ & \begin{tabular}{c|} 
Tingkat \\
Kepuasan
\end{tabular} & \begin{tabular}{|c|}
$\begin{array}{c}\text { Kepuasan } \\
\text { rata-rata }\end{array}$ \\
\end{tabular} \\
\hline $\mathrm{H} 1$ & \multirow{11}{*}{$\begin{array}{l}\text { Tangible (Bukti } \\
\text { Fisik) }\end{array}$} & Area parkir & 4.62 & 2.61 & $56 \%$ & $\begin{array}{c}\text { Kurang } \\
\text { puas }\end{array}$ & \multirow{11}{*}{$\begin{array}{l}\text { kurang } \\
\text { puas }\end{array}$} \\
\hline $\mathrm{H} 2$ & & Ruang makan & 4.77 & 2.85 & $60 \%$ & Puas & \\
\hline $\mathrm{H} 3$ & & Dekorasi restoran & 4.54 & 2.54 & $56 \%$ & $\begin{array}{c}\text { Kurang } \\
\text { puas }\end{array}$ & \\
\hline $\mathrm{H} 4$ & & Menu yang mudah dibaca & 4.07 & 2.23 & $55 \%$ & $\begin{array}{c}\text { Kurang } \\
\text { puas }\end{array}$ & \\
\hline H5 & & Kemasan menu yang menarik & 3.99 & 2.07 & $52 \%$ & $\begin{array}{c}\text { Kurang } \\
\text { puas }\end{array}$ & \\
\hline H6 & & Kenyamanan area makan & 4.85 & 2.47 & $51 \%$ & $\begin{array}{c}\text { Kurang } \\
\text { puas }\end{array}$ & \\
\hline H7 & & Kenyamanan meja kursi & 4.46 & 2.92 & $65 \%$ & Puas & \\
\hline $\mathrm{H} 8$ & & Personil yang bersih dan rapi & 4.30 & 2.77 & $64 \%$ & Puas & \\
\hline H9 & & Seragam personil pelayanan & 4.15 & 2.70 & $65 \%$ & Puas & \\
\hline $\mathrm{H} 10$ & & Kebersihan toilet & 4.46 & 2.92 & $65 \%$ & Puas & \\
\hline H11 & & Kebersihan area makan & 4.76 & 2.52 & $53 \%$ & Kurang puas & \\
\hline $\mathrm{H} 12$ & \multirow{7}{*}{$\begin{array}{c}\text { Reliability } \\
\text { (Kehandalan) }\end{array}$} & Konsistensi kualitas makanan & 4.85 & 2.92 & $60 \%$ & Puas & \multirow{7}{*}{ puas } \\
\hline $\mathrm{H} 13$ & & Ketepatan jumlah penagihan & 4.77 & 3.39 & $71 \%$ & Puas & \\
\hline H14 & & Ketepatan waktu pemesanan & 4.54 & 2.92 & $64 \%$ & Puas & \\
\hline $\mathrm{H} 15$ & & Pelayanan bebas kesalahan & 4.45 & 3.23 & $73 \%$ & Puas & \\
\hline H16 & & Respon ketika terjadi kesalahan & 4.38 & 3.15 & $72 \%$ & Puas & \\
\hline H17 & & Kecepatan pelayanan di jam sibuk & 4.92 & 2.54 & $52 \%$ & Kurang pua & \\
\hline H18 & & Menjaga ketepatan pelayanan & 4.46 & 3.16 & $71 \%$ & Puas & \\
\hline H19 & \multirow{5}{*}{$\begin{array}{c}\text { Responsiveness } \\
\text { (daya tanggap) }\end{array}$} & Melayani permintaan khusus dari pelanggan & 3.47 & 2.70 & $78 \%$ & Puas & \multirow{5}{*}{ puas } \\
\hline $\mathrm{H} 20$ & & Menjawab pertanyaan dengan lengkap & 4.23 & 2.82 & $67 \%$ & Puas & \\
\hline $\mathrm{H} 21$ & & Informasi detil mengenai menu & 4.23 & 2.70 & $64 \%$ & Puas & \\
\hline $\mathrm{H} 22$ & & Personil terlatih dan kompeten & 4.31 & 2.77 & $64 \%$ & Puas & \\
\hline $\mathrm{H} 23$ & & Dukungan pemilik pada karyawan & 3.85 & 2.85 & $74 \%$ & Puas & \\
\hline $\mathrm{H} 24$ & \multirow{2}{*}{$\begin{array}{c}\text { Assurance } \\
\text { (jaminan) }\end{array}$} & Keamanan dan keyakinan pada rekomendasi karyawan & 4.08 & 3.00 & $74 \%$ & Puas & \multirow{2}{*}{$\begin{array}{l}\text { sangat } \\
\text { puas }\end{array}$} \\
\hline $\mathrm{H} 25$ & & Rasa aman mengkonsumsi makanan & 4.31 & 3.74 & $87 \%$ & sangat puas & \\
\hline $\mathrm{H} 26$ & \multirow{4}{*}{ Emphaty (empati) } & Perhatian individual pada pelanggan & 3.78 & 2.81 & $74 \%$ & Puas & \multirow{4}{*}{ puas } \\
\hline $\mathrm{H} 27$ & & Pelanggan merasa diistimewakan & 3.77 & 2.83 & $75 \%$ & Puas & \\
\hline $\mathrm{H} 28$ & & Antisipasi pada kebutuhan dan keinginan pelanggan & 4.25 & 2.72 & $64 \%$ & Puas & \\
\hline $\mathrm{H} 29$ & & Pelayanan yang simpatik & 4.53 & 2.70 & $60 \%$ & Puas & \\
\hline & & rata-rata & 4.31 & 2.90 & $68 \%$ & $\mathbf{P u}$ & as \\
\hline
\end{tabular}

Sumber: data olahan

\section{Tangible (Bukti Fisik)}

Secara umum responden merasa kurang puas terkait dengan aspek-aspek yang terdapat pada variabel tangible. Dari kesebelas indikator yang dinilai 
responden, kenyamanan susunan meja dan kursi, seragam karyawan pelayanan dan kebersihan toilet mendapatkan penilaian tertinggi (masing-masing 65\%). Namun demikian jika dilihat dari indeks kepuasan yang masih berada dibawah $70 \%$ menunjukkan bahwa tingkat kepuasan yang diperoleh pelanggan masih jauh dari optimal.

Permasalahan aspek bukti fisik di adalah masih banyaknya indikator yang mendapatkan predikat kurang memuaskan oleh responden. Yang paling buruk adalah kenyamanan area makan yang dirasakan paling tidak memuaskan. Luas area yang kurang memadai menyebabkan ruang gerak pengunjung di area makan menjadi cukup terbatasi. Cukup banyak pelanggan yang mengeluhkan sempitnya area makan, terutama pada jam-jam sibuk di siang hari. Selain ruang gerak yang sempit, sirkulasi udara juga kurang nyaman karena didalam area makan tersebut tidak tersedia pendingin udara yang memadai. Keluhan paling banyak muncul dari pelanggan wanita. Pertama, terlebih karena banyak pengunjung yang merokok didalam area makan. Hal ini turut pula mengganggu kebersihan di area makan. Aspek higienitas ini memang masih mendapatkan poin penilaian yang juga kurang memuaskan oleh mayoritas pengunjung yang menjadi responden pada penelitian ini.

Masalah menu juga dirasakan kurang memuaskan. Desain kemasan menu kurang menarik dari aspek estetika dan kurang menarik untuk dibaca. Pada bagian eksterior dan interior, mayoritas responden kurang memberikan apresiasi yang positif karena segi dekorasi bagian luar dan dalam bangunan tidak dirancang estetis yang bisa menimbulkan daya tarik visual bagi pelanggan yang datang. Hal ini membuat kedatangan konsumen ke restoran hanya untuk menikmati makanan namun kurang dapat menikmati suasana makan yang menyenangkan.

\section{Reliability (Kehandalan Pelayanan)}

Tidak seperti yang terjadi pada variabel tangible, hasil penelitian justru menunjukkan bahwa pada variabel reliability rata-rata responden merasa puas dengan ketujuh indikator yang digunakan. Harapan pelanggan yang sangat tinggi pada aspek reliability ternyata dilaksanakan dalam kondisi yang memuaskan, kecuali hanya pada aspek kecepatan pelayanan di jam-jam sibuk.

Penilaian positif responden muncul dari aspek pelayanan karyawan yang jarang sekali membuat kesalahan. Dan jika pun terjadi kesalahan, karyawan dengan cepat bisa segera melakukan pemulihan pelayanan (service recovery), dari minimal mengucapkan permohonan maaf hingga kepada penggantian makanan atau minuman yang salah disajikan. Kemungkinan terjadinya kesalahan dalam bon tagihan pesanan juga relatif dipandang kecil oleh mayoritas responden. Keterbatasan menu sekali lagi merupakan faktor yang menguntungkan bagi pengelola restoran untuk tidak banyak melakukan kesalahan dan menjaga ketepatan pelayanannya.

Meskipun mendapatkan indeks yang minimal, namun pengelola rumah makan cukup mampu menjaga konsistensi rasa. Hal ini dimungkinkan mengingat seluruh racikan telah diproses terlebih dahulu. Jikapun terjadi 
perbedaan hanya dalam hal bahan-bahan tambahan seperti takaran kuah, sambal, kecap sesuai dengan selera konsumen masing-masing.

Permasalahan utama yang masih menjadi kendala adalah pada jam-jam sibuk (peak hours) sekitar pukul 11.30 hingga 13.30, dimana jumlah konsumen bertambah 3 hingga 4 kali lebih banyak dibandingkan pagi, sore atau malam. Banyaknya pesanan membuat karyawan pelayanan cukup direpotkan karena memang pengelola tidak menambah karyawan khusus untuk ini. Hanya saja, sesekali keluarga pemilik ikut terjun langsung membantu karyawannya untuk membantu di jam-jam tersebut. Hal ini menunjukkan adanya dukungan dari pemilik untuk ikut melayani pelanggan sebaik-baiknya.

\section{Responsiveness (Daya Tanggap)}

Hasil penelitian menunjukkan penilaian yang rata-rata sudah memuaskan. Aspek yang paling tinggi tingkat kepuasannya adalah kemampuan para karyawan dalam melayani permintaan-permintaan khusus dari pelanggan. Dukungan dari pemilik dalam memberikan pelayanan juga dinilai sudah memuaskan. Hal ini terlihat dari kemauan pemilik untuk ikut terjun langsung melayani pelanggan yang meningkat pada jam-jam sibuk di siang hari. Artinya, pemilik bisa merasakan kesulitan para karyawannya dan ikut merasakan bahwa pelanggan tidak akan nyaman apabila menununggu mendapatkan pesanannya terlalu lama. Para karyawan sendiri sudah cukup memahami tugasnya masingmasing dan telah memiliki product knowledge (pemahaman produk) yang cukup baik sehingga mereka dapat menjawab pertanyaan para pelanggan seputar menumenu yang dijual. Hal ini penting mengingat dalam hal makanan, konsumen dewasa ini cukup kritis untuk mempertanyakan segala hal terkait aspek kehalalan, higienitas dan lain sebagainya. Tampaknya dalam konteks ini pemilik sudah cukup membekali karyawannya sehingga terlatih dan kompeten dengan tugasnya.

\section{Assurance (Jaminan)}

Hasil penelitian menunjukkan bahwa dalam aspek jaminan, para pelanggan sudah sangat puas dengan sejumlah indikator yang ada pada aspek ini. Utamanya tentu saja adalah rasa aman ketika mengkonsumsi makanan. Karyawan cukup mampu meyakinkan para pelanggan yang menanyakan mengenai hal terkait kualitas maupun keamanan makanan. Banyak pelanggan tidak merasa khawatir dalam mengkonsumsi berbagai pilihan menu yang disediakan oleh rumah makan.

\section{Emphaty (Empati)}

Secara umum responden memberikan apresiasi yang memuaskan pada seluruh aspek empati yang ditunjukkan karyawan dan pemilik rumah makan. Hal yang paling mengesankan bagi konsumen adalah kemampuan karyawan dan pemilik dalam membuat konsumen merasa cukup diistimewakan. Caranya adalah karyawan maupun pemilik memberikan perhatian individual kepada sejumlah pelanggan. Mayoritas pelanggan memang bersifat reguler (rutin dengan frekuensi lebih dari 4 kali pernah mengunjungi rumah makan). Bagi para 
pelanggan, dikenal, disapa dan diajak berkomunikasi, tentunya merupakan kesenangan dan kebanggaan tersendiri. Hal ini bisa meningkatkan citra mereka di hadapan orang lain. Dalam hal ini, karyawan dan pemilik usaha kuliner sudah cukup berhasil dalam memberikan pelayanan yang simpatik, sehingga para pelanggan merasa cukup senang dan merasa dihargai setiap kali datang berkunjung. Hal ini pula yang mendorong banyak pelanggan untuk terus melakukan revisit (kunjungan kembali) dan repurchase (pembelian kembali) ke rumah makan.

\section{Analisis IPA}

Diagram Kartesius menggambarkan tingkat prioritas perbaikan pelayanan yang harus dilakukan pelaku usaha kuliner UMKM sebagaimana gambar dibawah ini:

\section{Gambar 2}

\section{Diagram Kartesius}

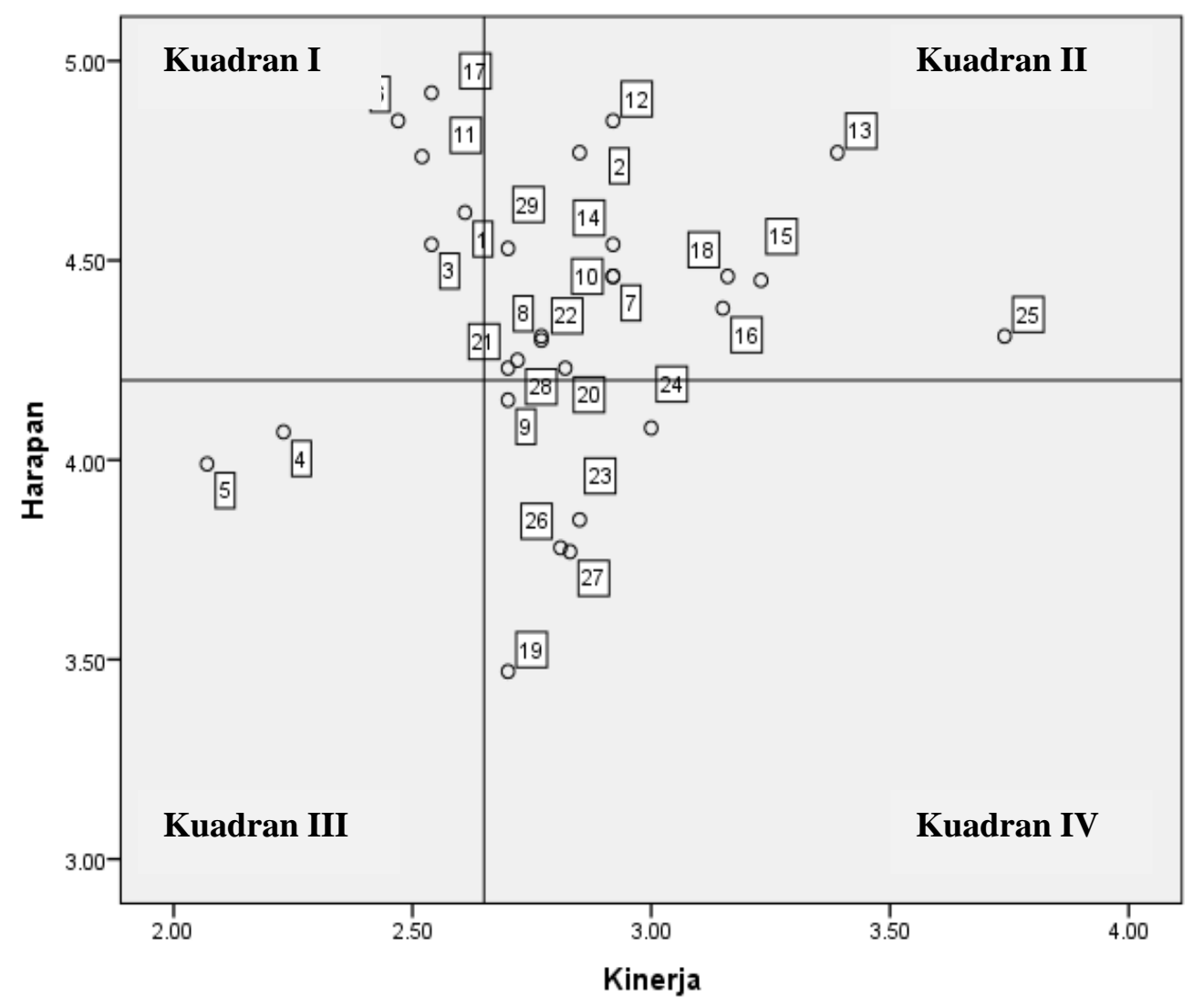

Sumber: Data olahan

Berdasarkan gambar diatas maka disimpulkan bahwa prioritas pelayanan yang perlu dilakukan perbaikan yang tercermin dari kuadran I dalam diagram Kartesius mencakup kepada: ketersediaan area parkir yang luas dan aman, dekorasi restoran yang menarik, kenyamanan di area makan, kebersihan di area 
makan serta kecepatan pelayanan di jam-jam sibuk. Hal ini menyebabkan masih terjadi kesenjangan kualitas yang menurut Lovelock \& Wright (2007:97) terjadi akibat kualitas kinerja (kenyataan) masih berada dibawah harapan pelanggan. Utamanya adalah mengenai kenyamanan di area makan sebagaimana yang disimpulkan pada penelitian Markovic, et.,al., (2010). Sedangkan sejumlah aspek pelayanan yang masuk pada kategori low priority adalah kemudahan membaca menu dan kemasan menu yang menarik.

Dalam banyak aspek, pelaku usaha kuliner UMKM pada penelitian ini sudah cukup berhasil memberikan pelayanan kepada para pelanggannya. Aspekaspek yang dirasakan sudah baik mencakup kepada: ruang makan, kebersihan, karyawan, rasa makanan, akurasi pemesanan, tagihan dan pelayanan, bahkan beberapa indikator menunjukkan kualitas yang lebih dari yang diharapkan oleh pelanggan seperti: seragam karyawan, permintaan khusus dari pelanggan, dukungan pemilik, keamanan, perhatian individu kepada para pelanggan.

\section{KESIMPULAN DAN REKOMENDASI}

Hasil penelitian menyimpulkan bahwa secara umum kualitas DINESERV relatif sudah cukup baik. Aspek-aspek yang dirasakan sudah cukup baik tercermin pada kuadran II dalam diagram Kartesius, yang terdiri dari: ruang makan, kenyamanan susunan meja dan kursi, kerapian dan kebersihan karyawan, kebersihan toilet, konsistensi kualitas masakan, ketepatan jumlah penagihan, ketepatan waktu pemesanan, pelayanan bebas kesalahan, respon ketika terjadi kesalahan, menjaga ketepatan pelayanan, menjawab pertanyaan secara lengkap, informasi detil mengenai menu, karyawan terlatih dan kompeten, rasa aman mengkonsumsi, antisipasi pada kebutuhan dan keinginan pelanggan serta pelayanan yang simpatik.

Dalam konteks pelayanan kuliner, maka implikasi yang paling perlu mendapatkan perhatian dan perbaikan adalah dengan menyempurnakan dimensi tangible (bukti fisik) yang belum memenuhi tingkat kepuasan pelanggan secara optimal. Harapan pelanggan yang sangat tinggi pada aspek tangible belum mampu dipenuhi oleh pengelola secara memuaskan. Pelanggan perlu merasakan kenyamanan di area makan ini, karena mayoritas pengunjung memilih cara mengkonsumsi di tempat dibandingkan dengan take away (bawa pulang).

Pengelola direkomendasikan menambah luas area parkir dengan menjalin kemitraan/ kerjasama sama berupa sewa tanah milik warga sekitar untuk bisa dijadikan tempat parkir kendaraan bermotor. Kenyamanan ruang makan bisa dioptimalkan dengan menata sistem sirkulasi udara di area makan. Pada jam-jam sibuk disarankan menambah orang yang dibayar perjam pada jam-jam sibuk, sehingga kecepatan pelayanan pada jam-jam ini masih bisa dijaga dan meminimumkan waktu tunggu bagi pelanggan.

Waktu menunggu datangnya pesanan hingga kepada waktu beristirahat setelah selesai makan, perlu menjadi perhatian pengelola usaha, karena pada momen-momen seperti inilah konsumen melakukan penilaiannya terhadap lingkungan rumah makan yang terlihat. Pengelola bisnis kuliner perlu menciptakan suasana belanja/konsumsi yang menyenangkan untuk memberikan 
kesan yang memuaskan pada benak pelanggan sehingga mereka berkenan untuk melakukan revisit maupun repurchase di masa yang akan datang.

\section{DAFTAR PUSTAKA}

Admin UMKM. Data Serta Jumlah UKM Kota Pekanbaru. Artikel Dunia UKM, diakses dari https://www.ukmriau.com/dunia-ukm/data-serta-jumlah-ukmkota-pekanbaru-dan-riau/, Maret 2016

Andreani, Fransisca. 2010. Analisa Kualitas Layanan Bisnis Makanan dan Minuman di Surabaya Ditinjau Dari Derajat Pemenuhan Kepuasan Konsumen. Jurnal Manajemen Pemasaran, vol. 5, No. 1, hal. 1-8

Ferdinand, Augusty. 2006. Metode Penelitian Manajemen. Badan Penerbit Universitas Diponegoro, Semarang

Kotler, Philip, dan Kevin Keller, 2007. Manajemen Pemasaran. Penerbit INDEKS, Jakarta

Lovelock, Christoper H., \& Lauren K. Wright. 2007. Manajemen Pemasaran Jasa. Penerbit Indeks, Jakarta

Markovic, S., S. Raspor, dan K. Segaric, 2010. Does Restaurant Performance Meet Customers' Expectations? An Assessment of Restaurant Service Quality Using A Modifief Dineserv Approach. Tourism and Hospitality Management, vol. 16, No. 2, pp. 181-195

Mason, K., S. Jones, dan J. Walton, 2013. Quick Service Restaurant Success Factors. Arkansas Tech University, US. Diakses dari http://www.aabri.com

Suroto, B., Hadiyati dan Afred Suci. 2015. Effective Model of Enterpreneurship Learning in Higher Education: Perspective in Indonesia. 2nd International Conference on Human Sustainability 2015, Malaysia.

Syuhada, Siti. 2014. Analisis Perkembangan Unit Usaha dan Penyerapan Tenaga Kerja Serta Pengaruhnya Terhadap Pendapatan Keluarga Pada Usaha Mikro, Kecil dan Menengah Berbasis Pangan Olahan di Kecamatan Pelayangan Kota Jambi. Jurnal Penelitian Universitas Jambi Seri Humaniora, vol. 16, No. 1, hal. 23-28. ISSN: 0852-8349

Tjiptono, Fandy, 2008. Strategi Pemasaran. Penerbit ANDI, Yogjakarta

Tjiptono, Fandy, dan Gregorius Chandra. 2007. Service, Quality \& Satisfacton. Penerbit Andi, Jogjakarta

Zuari, F.O., H. Widayani dan R.D. Daniel. 2013. Pengaruh Strategi Pemasaran Terhadap Penerimaan Bersih Restoran Omah Pincuk. Proceeding PESAT, vol. 5, hal. E-383 - E-389. ISSN: 1858-2559 